\title{
An Empirical Study of Tourist Hotels: Difference Analysis between International Tourist Hotel and Standard Tourist Hotel in Taiwan
}

\author{
Jui-Lung Chen ${ }^{1}$ \\ ${ }^{1}$ Department of Business Administration, National Chin-Yi University of Technology, Taiwan, R.O.C. \\ Correspondence: Jui-Lung Chen, Department of Business Administration, National Chin-Yi University of \\ Technology, No. 57, Sec. 2, Zhongshan Rd., Taiping Dist., Taichung 41170, Taiwan, R.O.C. Tel: \\ 886-4-2392-4505. E-mail: leonchen@ncut.edu.tw
}

Received: December 13, 2017

Accepted: January 27, 2018

Online Published: February 25, 2018

doi:10.5539/ijbm.v13n3p67

URL: https://doi.org/10.5539/ijbm.v13n3p67

\begin{abstract}
Based on the data from the Tourism Bureau of Taiwan (2017), this study investigated Taiwan's tourist hotels for the research period from 2014 to 2017. The differences between international tourist hotel and standard tourist hotel in the number of rooms, number of rooms occupied, occupancy rate, revenue, and number of employees are compared, and these items' impacts on hotel revenue are explored. This study expects to provide the hotel industry and the relevant government entities through the research results with the specific reference for their operation.
\end{abstract}

Keywords: international tourist hotel, standard tourist hotel, hotel revenue

\section{Introduction}

The global tourism industry continues to flourish, and the demand for quality of life and recreational activities has also risen sharply, which is inextricably linked with our lives. Many countries in the world strongly promote the tourism industry and are increasingly open in the aspect of tourist policy. The tourism industry is reputed as a "smokeless industry" and has a low environmental impact. It plays an important role in the economic development of the countries and can further promote the civilization and cultural development of a country. The tourism industry has become an important source of economy in many countries and created many employment opportunities as well as promoted the development and construction of related industries (Tung et al., 2008). In recent years, many new concepts in the operation of the tourism industry in the world and a new mode of exquisite management have brought about a steady stream of innovation and cast an important impact on our life and leisure needs (Chou 2005). With its long coastline, high mountains and widespread islands, Taiwan has rich cultural and natural tourism resources and has great potential for the development of the tourism industry. With the development tide of the global tourism industry, which has brought considerable business opportunities to the tourism industry in Taiwan, the government of Taiwan has always listed the tourism industry as one of the key industries. From the perspective of the source of economic returns, the tourism industry in Taiwan occupies a pivotal position (Tung et al., 2008). Under the concept of "Global Village", the tourism industry is said to be the most promising industry in the 21 st century. The "International Tourist Hotel" in lodging industry is a key part (Liao et al., 2016). However, with the prevalence of tourism, tourist hotels are also facing a more intense and competitive situation. In particular, the number of Taiwan's international tourist hotels has continued to increase in recent years, making Taiwan's tourist hotel industry highly competitive. The hotel should respect the uniqueness of the guests and provide personal and professional services according to the individual habits of the guests. As consumers pay more attention to their daily life and eating habits, people's consumption nowadays has not only focused on the practicality of the product itself, but also the pursuit of further emotional and psychic touch as well as consumption experience (Chou et al., 2015). As the hotel industry is a service industry, its sales of goods include tangible goods (such as hardware equipment) and intangible goods (such as services). In particular, the differences between the hotel industry and other industries can be characterized by such shortcomings as inelastic and evanescent short-term supply, non-durability, indivisibility, capital-intensity and high fixed costs, immovability and volatility in demand (Liao et al. et al., 2016). Hotel industry players should be more aggressive in designs that would enable lodging guests to change their perceptions and behavioral intentions through experience value enhancement (Chou et al., 2015). Therefore, the study explores the 
differences between Number of Rooms, Number of Rooms Occupied, Occupancy Rate, Revenue, and Number of employees in International Tourist Hotel and Standard Tourist Hotel in Taiwan, and investigates the impacts of various figures on hotel revenue. This study expects to provide the hotel industry and the relevant government entities with specific reference for their operation.

\section{Literature Review}

In the tourism industry, the hotel industry, which offers functions such as accommodation, dining, socializing, shopping and meeting venues, holds a key position (Hou et al., 2017). Tourist hotel is an indispensable part of the development of tourism industry and the most important part of tourism industry value chain. According to Article 2 of the Regulations for the Development of Tourist Hotels from the Ministry of Transportation and Communications, Taiwan, the tourist hotel business refers to the business of running tourist hotels, hosting tourist accommodation and providing services. Article 19 of the Regulations stipulates the business scope of its services, including: (1) guest room rental; (2) annexed restaurants, cafes and bars; (3) international conference halls; (4) other business related to tourist hotels and approved by the Ministry of Transportation and Communications (Tourism Bureau (Taiwan), 2016). According to the Tourism and Tourism Ordinance from Tourism Bureau, Ministry of Transportation and Communications, Taiwan, the tourist hotel industry refers to the profit-making business of providing accommodation and related services for international tourist hotels or standard tourist hotels. The division standards are based on the construction of the hotel and equipment standards (Tourism Bureau (Taiwan), 2016). As people's life quality improves across the world, the demand for hotel classes and equipment is getting higher and higher. Standard tourist hotels are less able to provide tourists with diversified dining, entertainment, leisure and shopping needs. In contrast, there is an increasing demand for international tourist hotels that provide quality accommodation (Tung et al., 2008). As the number of international tourist hotels and Number of Rooms show an increasing trend year by year, it can be seen that customers demand for high-quality international tourist hotels is increasing and international tourist hotels have become the mainstream market for tourist hotels in Taiwan (Tung et al., 2008). In 1977, the Taiwan government promulgated the Principles for Handling International Tourist Hotels in Urban Residential Areas and the Guidelines for Applying for Loans for Construction of International Tourist Hotels to stimulate the construction of large-scale tourist hotels. As of August 2017, the number of international tourist hotels in Taiwan has reached 79 with 22,422 rooms, and has shown signs of growth in recent years. By comparison, the number of standard tourist hotels has reached 48 with 6,840 rooms (Tourism Bureau (Taiwan), 2017). The four counties and cities with the most international tourist hotels are Taipei City with 27 hotels and 8,908 room, Kaohsiung City with 10 hotels and 3,599 rooms, Hualien County with 6 hotels and 1,519 rooms, and Tainan City with 6 hotels and 1,429 rooms. The top four major cities and counties are located in large metropolitan areas or tourist attractions, accounting for $62 \%$ of the national international tourist hotels. The two counties and cities with the most standard tourist hotels are Taipei City with 19 hotels and 2,575 rooms, and New Taipei City with 5 hotels and 448 rooms. The top 2 counties and cities are Taiwan's two largest metropolitan areas, accounting for $50 \%$ of the national standard hotels, while the number of standard tourist hotels in the rest counties is all under 4 (Tourism Bureau (Taiwan), 2017). With the improvement of Taiwan's economy, the demand for international tourist hotels with better service quality, more service choices and better decoration facilities has also been raised. In addition, Taiwan implemented "opening up Taiwan to mainland tourists" policy in 2008 and further liberalized "mainland independent tourists" in 2011. In recent years, Taiwan's tourist travel market has been dominated by mainland tourists (Lin, 2015). As a result, the number of tourists coming to Taiwan has been increasing year by year with the impact of the economic boom, the opening up Taiwan to mainland tourists policy, the governmental advocacy of external tourism and many other environmental variables. Therefore, in response to the business opportunities from the mainland tourists and the business tourists, the number of international tourist hotels in Taiwan has been on the increase in recent years. In addition, the number of standard tourist hotels with poor service quality and facilities has been reduced. By 1992, the number of international tourist hotels exceeded the number of standard tourist hotels for the first time. Besides, the number of international tourist hotels was increasing, and the number of standard tourist hotels was gradually decreasing (Tung et al., 2008).

The international hotel brands in Taiwan mostly come from the United States, Europe or Japan. Those brands are operated worldwide, and there is expected growing popularity by joining the membership organization. For example, Landis and Sherwood became members of the reservation system of Leading Hotels of the World respectively in 1983 and 1994. Sherwood is also a member of Preferred Hotels Reservation System, and Far Eastern Plaza Hotel is a member of Shangri-La Hotels Reservation System. In addition, relying on its advantages in aviation and maritime transportation, Evergreen Group established a management company in Taoyuan and founded Evergreen Laurel Hotel chain. Apart from Taiwan's bases at Keelung, Taichung and Taipei, the group 
has set up overseas bases in Penang, Bangkok and Paris, which makes it a highly internationalized hotel in Taiwan (Cheng and Lin 2008). Hotel industry is an industry characterized by big investment and slow recovery rate. For the hotel industry, although the various service modes provided can meet the basic needs of some customers, the service ways and contents should keep abreast of customer needs and trends in this diversified modern society, especially in current increasing trend in both hotel sizes and business types (Chou et al., 2015).

\section{Research Methodological}

\subsection{Research Sample and Data Source}

The main purpose of this study is to explore the differences in Number of Rooms, Number of Rooms Occupied, Occupancy Rate, Revenue, and Number of employees between international tourist hotels and standard tourist hotels in Taiwan, and to discuss the impacts of various factors on hotel revenue. Therefore, based on the four-year data from 2014 to 2017 in the Tourism Bureau, Ministry of Transportation and Communications, Republic of China (Taiwan) (2017), this study adopts the international tourist hotels and standard tourist hotels in Taiwan as the research sample in order to probe into the tourist hotels in Taiwan. The information includes the number of international tourist hotels and standard tourist hotels, Number of Rooms, Number of Rooms Occupied, Occupancy Rate, Revenue and the number of employees (divided into Room Dep., F\&B Dep., Adm. Dep. and Other Dep.) and hotel revenue (divided into Room revenue and F\&B revenue).

\subsection{Definitions of Research Variables}

The variables in this study are mainly divided into dependent variables and independent variables. The dependent variable is the Total Revenue, and other independent variables include Number of Rooms, Number of Rooms Occupied, Occupancy Rate, Average Room Rate, Room Revenue, F\&B Revenue, Number of employees (Room Dep.), Number of employees (F\&B Dep.), Number of employees (Adm. Dep.), Number of employees (Other Dep.) and Total Number of employees.

\subsection{Statistical Analysis}

Firstly, the descriptive statistical part refers to the data description on Number of Rooms, Number of Rooms Occupied, Occupancy Rate, Average Room Rate, Room Revenue, F\&B Revenue, Number of employees (Room Dep.), Number of employees (F\&B Dep.), Number of employees (Adm. Dep.), Number of employees (Other Dep.) and Total Number of employees in international tourist hotels and standard tourist hotels in Taiwan, and is tested by independent sample t-test. The differences in the market positioning variables of these two different types of hotels are compared to determine whether there are significant differences in the variables. Then, multiple regression analysis is applied with the Total Revenue as the dependent variable, and other variables as independent variables to carry out multiple regression analysis on international tourist hotels and standard tourist hotels.

\section{Results}

\subsection{Comparative Analysis of International Tourist Hotels and Standard Tourist Hotels}

It can be known from Table 1 that there are statistically significant differences in Number of Rooms, Number of Rooms Occupied, Occupancy Rate, Average Room Rate, Room Revenue, F\&B Revenue, Number of employees (Room Dep.), Number of employees (F\&B Dep.), Number of employees (Adm. Dep.), Number of employees (Other Dep.) and Total Number of employees of international tourist hotels and standard tourist hotels in Taiwan $(\mathrm{p}<0.01)$, which will be illustrated hereunder.

Table 1. Descriptive statistics of research sample and t-test (average values from January 2014 to August 2017)

\begin{tabular}{lllllll}
\hline & \multicolumn{2}{c}{ International } & \multicolumn{2}{c}{ Standard } & \multicolumn{2}{c}{$\mathrm{t}$-test } \\
\multicolumn{1}{c}{ Average } & \multicolumn{2}{c}{ SD } & Average & SD & $\mathrm{p}$ & $\mathrm{t}$ \\
\hline Number of Rooms & 21092.93 & 645.26 & 6088.84 & 333.62 & $.000^{* *}$ & 137.01 \\
Number of Rooms Occupied & 445977.71 & 27142.02 & 116173.34 & 7683.78 & $.000^{* *}$ & 77.55 \\
Occupancy Rate & .6955 & .0471 & .6284 & .0473 & $.000^{* *}$ & 6.66 \\
Average Room Rate & 132.02 & 4.68 & 102.17 & 5.17 & $.000^{* *}$ & 28.39 \\
Room Revenue & 58.87 & 4.03 & 11.87 & 1.04 & $.000^{* *}$ & 74.87 \\
F\&B Revenue & 61.17 & 8.22 & 10.64 & 1.72 & $.000^{* *}$ & 39.93 \\
Total Revenue & 136.99 & 10.60 & 20.51 & 2.43 & $.000^{* *}$ & 68.22 \\
Number of employees (Room Dep.) & 6533.20 & 177.56 & 1522.91 & 86.62 & $.000^{* *}$ & 168.23 \\
Number of employees (F\&B Dep.) & 10405.41 & 368.15 & 1929.27 & 125.49 & $.000^{* *}$ & 144.56 \\
\hline
\end{tabular}




\begin{tabular}{lllllll}
\hline Number of employees (Adm. Dep.) & 3513.75 & 103.09 & 684.59 & 51.01 & $.000^{* *}$ & 163.16 \\
Number of employees (Other Dep.) & 2658.07 & 120.26 & 486.39 & 49.10 & $.000^{* *}$ & 11.091 \\
Total Number of employees & 23110.43 & 687.62 & 4623.16 & 292.84 & $.000^{* *}$ & 164.08 \\
\hline
\end{tabular}

Note. The unit of revenue is US dollar million; $* \mathrm{p}<.05, * * \mathrm{p}<.01$

(1) Number of Rooms: The average Number of Rooms in international tourist hotels is about 3.5 times the average Number of Rooms in standard tourist hotels. The reason for this phenomenon is that with the improvement of the global economy and the increasing demand from domestic and foreign tourists for international tourist hotels with better service quality, there are a lot more rooms in international tourist hotels than standard tourist hotels.

(2) Number of Rooms Occupied: The average Number of Rooms Occupied in international tourist hotels is about 3.8 times the average Number of Rooms Occupied in standard tourist hotels. The reason is similar to above.

(3) Occupancy Rate: The average Occupancy Rate of International Tourist Hotel is slightly higher than that of the standard tourist hotel by $6.7 \%$. The facilities, decoration, service quality and brand image of international tourist hotels are mostly superior to those of standard tourist hotels, thus making them more attractive for tourists and increasing the occupancy rate of international tourist hotels.

(4) Average Room Rate: The Average Room Rate at international tourist hotels is higher than that of standard tourist hotels by approximately USD30. The facilities, decoration, service quality and brand image of international tourist hotels are mostly superior to those of standard tourist hotels. Besides, the international tourist hotel market is positioned as a more sophisticated and advanced market, so its higher operating costs make the average room rate higher than that of the standard tourist hotels.

(5) Room Revenue: The average Room Revenue of international tourist hotels is about 5 times that of standard tourist hotels. Continuing the above, as the Number of Rooms Occupied, Occupancy Rate and Average Room Rate of international tourist hotels are higher than those of the standard tourist hotels, the Room Revenue of international tourist hotels is also higher.

(6) F\&B Revenue: The average F\&B Revenue of international tourist hotels is about 5.75 times that of standard tourist hotels. The international tourist hotels offer more diversified and larger-scale catering services, which makes them more appealing. Thus, their F\&B Revenue is much higher than that of standard tourist hotels.

(7) Total Revenue: As mentioned above for Room Revenue and F\&B Revenue, international tourist hotels offer diversified dining, entertainment, leisure and shopping services. Therefore, international tourist hotels which offer a wide range of services are more attractive, making the Total Revenue of international tourist hotels much higher than that of standard tourist hotels.

(8) Number of employees (Room Dep.): The average Number of employees (Room Dep.) of international tourist hotels is about 4.3 times that of standard tourist hotels. This is related to that the Number of Rooms, Number of Rooms Occupancy Rate Occupied of international tourist hotels are higher than those of standard tourist hotels. From the perspective of times, the average Number of employees per room is higher in international tourist hotels, thus providing better service quality.

(9) Number of employees (F\&B Dep.): The average Number of employees (F\&B Dep.) of international tourist hotels is about 21 times that of standard tourist hotels. This is consistent with that the F\&B Revenue of international tourist hotels is higher than that of standard tourist hotels. However, from the perspective of times, the Number of employees in F\&B Dep. of international tourist hotels is much higher than that of standard tourist hotels, thus providing better service quality.

(10) Number of employees (Adm. Dep.): The average Number of employees (Adm. Dep.) of international tourist hotels is about 5 times that of standard tourist hotels. It can be seen that the international tourist hotels require more management manpower due to their larger sizes.

(11) Number of employees (Other Dep.): The average Number of employees (Other Dep.) of international tourist hotels is about 5.5 times that of standard tourist hotels. It can be seen that the international tourist hotels require more manpower in other departments due to their larger sizes.

(12) Total Number of employees: The average Total Number of employees of international tourist hotels is about 5 times that of standard tourist hotels. It can be seen that the international tourist hotels require more manpower due to their larger sizes. 


\subsection{Multiple Regression Analysis}

With Total Revenue as the dependent variable and others variables as the independent variables, multiple regression analysis is carried out on the international tourist hotels and the standard tourist hotels. Table 2 shows the results. In both the international tourist hotels and the standard tourist hotels, the adjusted $\mathrm{R}^{2}$ is very high, which will be illustrated hereunder.

Table 2. Multiple regression analysis of tourist hotels (2014 2005)

\begin{tabular}{lll}
\hline & \multicolumn{1}{c}{ Variable: Total Revenue } & \\
Variable & International & Standard \\
\hline Number of Rooms & .025 & $.082^{*}$ \\
Number of Rooms Occupied & $-.586^{*}$ & .131 \\
Occupancy Rate & .014 & .045 \\
Average Room Rate & $-.654^{*}$ & .114 \\
Room Revenue & $.664^{*}$ & .246 \\
F\&B Revenue & $.880^{* *}$ & $.784^{* * *}$ \\
Number of employees (Room Dep.) & $.205^{* *}$ & -.066 \\
Number of employees (F\&B Dep.) & .000 & .000 \\
Number of employees (Adm. Dep.) & .014 & -.032 \\
Number of employees (Other Dep.) & $.084^{*}$ & -.039 \\
Total Number of employees & $-.331^{* *}$ & .073 \\
F value & $838.555^{* *}$ & $1100.472^{* * *}$ \\
$\mathrm{R}^{2}$ & .995 & .996 \\
\hline
\end{tabular}

Note. Only standardized regression coefficient values $(\beta)$ are shown in the table; ${ }^{*} \mathrm{p}<.05,{ }^{* *} \mathrm{p}<.01$.

(1) For the international tourist hotels, Room Revenue, F\&B Revenue, Number of employees (Room Dep.) and Number of employees (Other Dep.) show a positive significant correlation. Therefore, higher Room Revenue, F\&B Revenue, Number of employees (Room Dep.) and Number of employees (Other Dep.) will increase the hotel competitiveness and enable them with better operating performance. In contrast, Number of Rooms Occupied, Average Room Rate and Total Number of employees show a negative significant correlation. Therefore, hotels should pay attention to the development of the room rate and whether the allocation of excessive manpower affects the operating revenue. Beta value is used to analyze the impact of Total Revenue. The larger the Beta value is, the greater the influence will be. From Table 2, we can see that F\&B Revenue and Room Revenue have the largest influence, which means that the higher F\&B Revenue and Room Revenue are, the higher Total Revenue will be.

(2) For the standard tourist hotels, only Number of Rooms and F\&B Revenue show a positive significant correlation. Therefore, higher Number of Rooms and F\&B Revenue will increase the competitiveness of standard tourist hotels and enable them with better operating performance. Beta value is used to analyze the impact of Total Revenue. The larger the Beta value is, the greater the influence will be. We can see that F\&B Revenue and Room Revenue have the largest influence, which means that the higher F\&B Revenue and Room Revenue are, the higher Total Revenue will be.

\section{Conclusions and Discussion}

According to the results of this study, the differences between International Tourist Hotel and Standard Tourist Hotel in Taiwan in Number of Rooms, Number of Rooms Occupied, Residential Rates, Revenue, and Number of employees, etc., and the results of multiple regression analysis are statistically significant. Tourist hotels are among the most important tourist attractions. Taiwan's international tourist hotels and standard tourist hotels are mostly located in the metropolitan area, while the well-run tourist hotels usually have a good location. Besides, their food and beverage revenues play an important part in the total revenue of the hotel. The promotion of the government's tourist policy also contributes to the management of tourist hotels (Tung et al., 2008). In recent years, Taiwan's government has been pushing Taiwan's tourism industry in the hope of boosting tourism revenue. In addition, Taiwan's Executive Yuan has also vigorously promoted "tourist multiplier program" in recent years to speed up the development of the tourist service industry. Hotel business is a kind of comprehensive and diversified business enterprise complex. The supply of goods and services cannot be mass-produced and stored in advance, and it is also involved in the economic life of human beings. Hotel services for individual 
practitioners refer to the direct sales of intangible goods, and the quality of service has a direct impact on the overall hotel image. Therefore, "humanistic" factors determine the success of the hotel industry (Yang and Lin, 2004). In particular, the hotel industry is a labor-intensive industry, which mainly relies on providing services for its guests to make profits. Of all the operating costs, the most expensive is the labor cost. Compared with other industries, the hotel industry obviously needs to hire more workers, which makes it the standard labor-intensive industry. Furthermore, the quality of human resources was also important, so the supply and demand of manpower is another important topic (Chou, 2005). The competition in the service industry is getting fiercer. Enterprises are gradually focusing on the internal management of the company. They think that the employees are the most important resources in the organization and retain the excellent talents through the well-planned incentive system, which has become an important issue in the management of service organizations (Chen, 2015). In particular, the peak-slack season phenomenon in tourism industry is very clear, even on the weekly and daily scale. How to balance the difference between slack and peak seasons so that the demand and supply can be completely balanced without any waste of resources requires proper management.

Intangible services are often combined with the people, things and objects. As consumers measure the service quality by equipment and prices, these excellent planning of the people, things and objects will reduce the perceived risk of customers, such as endorsement by celebrities, high-quality furniture equipment, luxurious decoration facilities and employee uniforms, etc. Improving the quality of the tangibles associated with service activities can enable the customers to have the confidence to reduce their perceived risk and be willing to buy back again (Chou, 2005). The key service points in the future hotel services include the pursuit of efficiency, communication focus, mobility and the provision of customized services and one-stop services for hotel management. Management organizational structure should overcome the disadvantages of excessive management levels, lack of information transparency, high marketing and sales expenses, and low efficiency. It should avoid the small division of labor and should tend to be small, simple and flat in management organizational structure (Cheng and Lin, 2008). Therefore, good human resource management can improve employee service quality, increase employee productivity, and enhance employee satisfaction and loyalty. Employees of International Tourist Hotel can be better educated and trained, thus enhancing the quality of their employees and service quality and resulting in an increase in output value. The Standard Tourist Hotel should set the standard operating procedures and regular employee training courses, organize and encourage employees to participate in lectures, seminars, training sessions to enhance employees' professional knowledge and skills. By enhancing employee service levels, they can increase their employee output (Tung et al., 2008). If the hotels can set up a career management system according to the needs of the employees, they can reduce the worries of employees and enhance the employees' motivation (Elsdon and Iyer, 2000). The hotels may consider devoting more resources to the selection and training of employees. Secondly, they can set up a system of customer suggestions, pay attention to customer complaints and satisfaction, and encourage good welfare and tips to play an appropriate marketing incentive (Chou 2005). Because the attitude of the service employees will directly affect the customer's willingness and satisfaction of purchase, if the hotels carefully select employees who are in direct contact with the customer, and provide them with incentives, their work willingness, work value and service quality will be improved (Chou, 2005). The service quality needs to be delivered by front-line employees, while employee service attitudes are strongly influenced by the socialization of employees from the hotel culture. Organizational business strategies and leadership must also rely on cultural support and maintenance (Shen et al., 2010).

The market of the tourist hotel industry is under intense competition, with the increase in operating costs and the substantial reduction in the operating profit. In order to increase the operating profit, the tourist hotel industry aggressively improves their service quality to increase customer base. Besides, simplification of labor cost has also become an important business strategy to reduce costs (Shen, et al., 2010). In response to customers' increasing demand for diversified facilities and services, the tourist hotel industry improves the hardware facilities and software services. Therefore, they also need to increase the number of employees in order to enhance the proportion of their services so that customers enjoy better services. Therefore, it is recommended that the standard tourist hotel industry should consider and measure the size of the hotel and the services it provides, and thus hire an appropriate amount of employees to maintain its service quality (Tung et al., 2008). How to use the concept of knowledge management in the tourist hotel industry, and strengthen the competitiveness of enterprises through the sharing and transfer of knowledge among the workers in the organization, and create new knowledge is of great importance in practice (Yang and Lin, 2004). For example, employee training programs can be arranged to improve attendance courtesy, language skills, and check-in/check-out efficiency in order to enhance service quality and attract tourists (Hou et al., 2017). 
Operating revenue is the most important factor that affects the closure of standard tourist hotel. Its revenue from catering services accounts for the highest proportion of operating revenue. Therefore, it is expected to enhance the characteristics of its catering business and introduce various activities and promotional programs in line with the holiday season and the peak-slack seasons to raise catering revenue. An important factor that affects customers' accommodation in hotels is the location of the hotel. As a result, the hotel is not only located in convenient traffic, but also offers more parking spaces to improve customer satisfaction (Tung et al., 2008). On one hand, standard tourist hotel can be devoted to enhancing its hardware rating and service quality so as to raise the average room rate, thus realizing of the increase in operating revenue. On the other hand, food and beverage revenue is also increasingly an important part. Hotels can open up the catering market more and create demand to fill the shortfall in room revenue (Tung et al., 2008).

With the changes in customer demand and intensified market competition, the hotel marketing strategy is diversified, and hotels will pay more and more attention to market segmentation. They win the target customers through the development of personalized products and the provision of individualized services. Concepts of integrated marketing, profitability-based marketing, relationship marketing, database marketing and Internet marketing continue to emerge. Therefore, apart from the establishment of hotel brands, the hotel differences should be highlighted (Cheng and Lin, 2008). A good brand image can improve customer loyalty and hence increasing occupied room rate, while unique experience can be translated into hotel success (Zhang et al., 2009). Due to the intangible nature of the tourist service, customers cannot experience the service in advance. Therefore, through the franchise chain and strategic alliances with famous brands, the tourist hotel industry will enhance its competitiveness, service quality and brand image, and make the customers feel comfortable with the quality of the products and services before purchasing the hotel products and services. Good service quality also contributes to the customer reflow rate (Tung, et al., 2008). Taiwan's abundant natural resources have seen an ever-increasing number of tourists visiting Taiwan. If the government can combine the power of the private sector and fully cooperate with the leisure industry, the tourist hotel industry in the country will definitely flourish.

\section{References}

Allen, L. R., Hafer, H. R., Long, P. L., \& Perdue, R. R. (1993). Rural residents' attitudes toward recreation and tourism development. Journal of Travel Research, 31(4), 27-33. https://doi.org/10.1177/004728759303100405

Bureau of Consular Affairs, Ministry of Foreign Affairs, Republic of China (TAIWAN) (2017). Retrieved from: http://www.boca.gov.tw/content?mp=1\&CuItem $=32$

Chou, M. (2005). On the characteristics and development strategies of tourism industry. Newsletter for Research of Applied Ethics, 36, 26-34.

Chou, W., Liang, L., Yen, W., \& Xie, Y. (2015). The Effect of experiential value on behavioral intention in hotel consumer perceived value: The moderating effect of atmosphere. Journal of Chinese Trend and Forward, $11(2), 113-127$.

Chen, I. (2015). An Inquiry into the essential factors affecting the job satisfaction of staff incentives in international tourist hotels and business hotels. Journal of Leisure and Sports Management, 2, 33-42.

Cheng, J., \& Lin, G. (2008). Groping and specialty: The correlation between entry strategy and business model of hotel industry. Industry Management Review, 3(1), 23-26.

Elsdon, R., \& Iyer, S. (2000). Keeping the workers at Sun Microsystems. Human Resource Management International Digest, 8(3), 13-14.

Hou, P., Chen, C., \& Pao, H. (2017). Room pricing determinants of the international tourist hotel in Taiwan, Journal of Tourism and Leisure Management, 5(1), 138-146. https://doi.org/10.6510/JTLM

Liao, C., Chang, C., \& Hong, C. (2016). The investigation of business performance for international tourism hotels in Taiwan: Applying the panel data model. Vanung Commercial Journal, 21, 69-84.

Lin, W. (2015). International tourist hotel staff to explore related cognitive and attitude of mainland visitors. Journal of Recreation Sport and Health Promotion, 8(1), 36-58. https://doi.org/10.6204/JRSHP.2015.08.04

Shen, C., Chen, C., \& Shen, C. (2010). Research on the relationships of organizational culture to organizational performance: An empirical study of tourist hotels in Kaohsiung. Web Journal of Chinese Management Review, 13(1), 1-21.

Tung, G., Lin. H., \& Che, S. (2008). An empirical study for the market position, competition and closure of 
tourism hotels in Taiwan. Journal of Leisure and Tourism Industry Research, 3(1), 94-110.

Tourism Bureau, Ministry of Transportation and Communications, Republic of China (Taiwan) (2016). Retrieved from http://admin.taiwan.net.tw/law/law_d.aspx?no=130\&d=643

Tourism Bureau, Ministry of Transportation and Communications, Republic of China (Taiwan) (2017). Retrieved from http://admin.taiwan.net.tw/statistics/

Yang, C., \& Lin, E. (2004). The cases study on knowledge management of hotel-keeping. Journal of Hospitality and Home Economics, 1(1), 105-126. https://doi.org/10.6572/JHHE

Zhang, J., Dewald, B., \& Neirynck, B. C. (2009). Experiential values for casino hotels in Macao. Journal of Quality Assurance in Hospitality \& Tourism, 10(2), 75-92. https://doi.org/10.1080/15280080902946285

\section{Copyrights}

Copyright for this article is retained by the author(s), with first publication rights granted to the journal.

This is an open-access article distributed under the terms and conditions of the Creative Commons Attribution license (http://creativecommons.org/licenses/by/4.0/). 